\title{
Kommentar
}

\section{Hensiktsmessige anbefalinger?}

Dette er en kasuistikk i sjangeren «pasient oppsøker udugelig fastlege, men heldigvis kommer han etter hvert til en superspesialist». Denne sjangeren hensetter meg i dårlig humør. Den brukes ikke sjelden i undervisning av medisinstudentene ved Universitetet i Oslo - noe som kollegiet ved Avdeling for allmennmedisin forsøker å bekjempe. Men det som virkelig gir grunn til dårlig humør i denne kasuistikken er det som faktisk skjer hos fastlegen: En ung mann med utflod og dysuri blir sendt hjem med et klapp på skulderen og forsikring om at plagene nok vil gå over. Dette er selvsagt uakseptabelt. Likevel er det min frimodige påstand at det store flertall fastleger i Norge vil tenke på seksuelt overførbar sykdom hos en slik pasient, forhøre seg om seksuell praksis og ta relevante prøver. Det er det i hvert fall ingen tvil om at legen bør gjøre.

Vi lever i en heteronormativ hverdag. Nyere norsk forskning viser at fastleger ofte ikke tenker seg muligheten av at pasienten kan være homofil eller lesbisk (1). Alt helsepersonell trenger vedvarende oppmerksomhet på og aksepterende holdninger til at den pasienten som sitter foran en kan ha en seksuell legning og/eller praksis som er forskjellig fra ens egen. Og ikke minst trenger helsepersonell kunnskap om spesifikke helseproblemer for homofile og lesbiske deriblant et annet smittepanorama, som beskrevet her.

Hvorvidt fastleger skal følge Folkehelseinstituttets anbefaling og kjøre alle menn som har sex med menn i sin praksispopula- sjon gjennom testbatteriet beskrevet i ramme 2 hvert år, er et annet spørsmål. Det er ikke grenser for hva såkalte «SIFs» (singel issue fanatics) kan liste opp av ønsket risikoforebygging for $\sin$ risikogruppe enten det gjelder hypertensjon, lipider, bryst-, prostata-, tykktarm- eller livmorhalskreft, overvekt, røyking, diabetes, osteoporose, føflekker, alkohol - eller altså menn som har sex med menn. Alt i beste mening, men med varierende grad av forskningsmessig belegg for positiv effekt av innsatsen (2) Er det vist at årlig screening av symptomfrie menn som har sex med menn reduserer forekomsten av hiv og syfilis i Norge? Noen må beholde et kritisk helhetssyn på implementeringen av populasjonsbaserte anbefalinger i den daglige fastlegepraksis $(3,4)$ - der dårligere tid til å behandle syke, overdiagnostisering, falskt positive prøver og mye engstelse kan bli uønskede konsekvenser $(5,6)$.

Pasienten viste seg å være nysmittet med hiv og gonoré. For en utenforstående er det ubegripelig at oppegående, informerte homofile i 2013 kan være bekjent av å utsette seg selv og ikke minst andre for slik smitte. Da hiv ble kjent som et folkehelseproblem, sto de homofile organisasjonene og miljøene frem og tok ansvar for å begrense epidemien. Etter en stabil smittespredning i 1990-årene har antall hivtilfeller nå tiltatt, ikke minst pga. en betydelig økning av smitte blant menn som har sex med menn, gjerne i settinger med tilfeldig sex (7). Det kan se ut til at det nå er den personlige frihet som kommer først - deriblant også kondomfrihet ved saunabesøk. På tide å kreve en holdningsendring?

\section{Mette Brekk}

mette.brekke@medisin.uio.no

Avdeling for allmennmedisin

Institutt for helse og samfunn

Universitetet i Oslo

Kurbadet legesenter

Mette Brekke (f. 1953) er professor og fastlege. Forfatter har fylt ut ICMJE-skjemaet og oppgir ingen interessekonflikter.

\section{Litteratur}

1. Bjørkman M, Malterud K. Lesbian women's experiences with health care: a qualitative study. Scand J Prim Health Care 2009: 27: 238-43.

2. Woolf $\mathrm{SH}$, Harris R. The harms of screening: new attention to an old concern. JAMA 2012; 307: $565-6$.

3. Buetow S, Getz L, Adams P. Individualized population care: linking personal care to population care in general practice. J Eval Clin Pract 2008; 14 $761-6$.

4. Getz L, Sigurdsson JA, Hetlevik I. Is opportunistic disease prevention in the consultation ethically ustifiable? BMJ 2003; 327: 498-500.

5. Moynihan R, Doust J, Henry D. Preventing over diagnosis: how to stop harming the healthy. BMJ 2012: 344: e3502.

6. Glasziou P, Moynihan R, Richards T et al. Too much medicine; too little care. BMJ 2013; 347: f4247.

7. Folkehelseinstituttet. Hivsituasjonen i Norge i 2011. www. fhi.no/artikler/?id=96186 (16.9.2013).

Mottatt 5.9. 2013 og godkjent 17.9.2013. Redaktør: Hanne Støre Valeur. 